\title{
The historical background to the Marriage (Wales) Act 2010
}

Article

Accepted Version

Roberts, N. (2011) The historical background to the Marriage (Wales) Act 2010. Ecclesiastical Law Journal, 13 (1). pp. 3956. ISSN 0956-618X doi:

https://doi.org/10.1017/S0956618X10000785 Available at https://centaur.reading.ac.uk/21693/

It is advisable to refer to the publisher's version if you intend to cite from the work. See Guidance on citing.

To link to this article DOI: http://dx.doi.org/10.1017/S0956618X10000785

Publisher: Cambridge University Press

All outputs in CentAUR are protected by Intellectual Property Rights law, including copyright law. Copyright and IPR is retained by the creators or other copyright holders. Terms and conditions for use of this material are defined in the End User Agreement.

\section{www.reading.ac.uk/centaur}

\section{CentAUR}

Central Archive at the University of Reading

Reading's research outputs online 


\section{THE HISTORICAL BACKGROUND TO THE MARRIAGE (WALES) ACT}

\section{0}

NICHOLAS ROBERTS Principal Teaching Fellow, School of Law, University of Reading

\section{Abstract}

The Marriage (Wales) Act 2010 illustrates that a disestablished church will always occupy an intermediate position between an established church and one which has never been established: the Church in Wales needed an Act to reform its marriage law, whereas paradoxically the Church of England legislated for itself by Measure. The article outlines how the provisions on marriage evolved during the passage of the disestablishment legislation; accepts the validity of contemporaneous arguments based on inconsistency; and outlines previous occasions when the marriage laws of England and of Wales have fallen out of step. It concludes by accepting that the continued establishment of the marriage law in Wales is inconsistent, but that any change is likely to depend on a wholesale reform of marriage law.

\section{INTRODUCTION}

The Marriage (Wales) Act 2010 (MWA 2010) is an intriguing piece of legislation. It originated as a private member's bill, drafted by the Church in Wales, ${ }^{1}$ and introduced into the House of Lords by Lord Rowe-Beddoe. ${ }^{2}$ With remarkably good fortune it managed to pass all its stages and to receive the Royal Assent before the dissolution of Parliament prior to the May 2010 General Election. Its intention is simple: to bring the marriage law of Wales into line with the changes effected in England by the Church of England Marriage Measure of 2008. This Measure allows those wishing to be married to be married not only in the parish church of the parish in which one of the parties resides, but also in the church of any parish with which one of the parties has a 'qualifying connection'. 3 This is broadly defined, allowing someone to be married in the church of a parish where: ${ }^{4}$

i. One of the parties to the marriage was baptised or confirmed;

ii. One of the parties had habitually attended public worship ${ }^{5}$ for any period of six months;

\footnotetext{
${ }^{1}$ The progress from start to finish of the change in the law was remarkably rapid, as the move to bring the law in Wales in line with that in England seems to have originated with a Private Members' Motion (No 09/13) proposed, debated and passed by the Governing Body of the Church in Wales at its meeting on 21 and 22 April 2009, and which requested the Standing Committee 'take the appropriate steps to encourage the enactment of such legislation': see < http://www.churchinwales.org.uk/structure/govbody/sep09/docs/GBApril09Minutes.doc > accessed 6 September 2010. As the Act received the Royal Assent on 18 March 2010, it was passed within 11 months of the proposal first being raised at the Governing Body.

${ }^{2}$ Chairman of the Representatative Body of the Church in Wales.

${ }^{3}$ Marriage Measure 2008, s 1(1); applied in Wales by the MWA 2010, s 2(1).

${ }^{4}$ Marriage Measure 2008, s 1(3); applied in Wales by the MWA 2010, s 2(3).

${ }^{5}$ It should be noted that this is a significant extension on the provision of the Marriage Act 1949 (MA 1949) (s 6(4)) allowing for the calling of banns and the solemnisation of marriage in a church which is the 'usual place of worship' of one of the parties: for a church to be considered one's usual place of worship, it is essential that one be on the
} 
iii. One of the parties had resided for a period of at least six months;

iv. A parent of one of the parties had resided, or had habitually attended public worship, for a period of at least six months (provided that in either case this was during the lifetime of the party to be married);

v. A parent or grandparent of one of the parties had been married.

It is stated that the Measure is a pastoral response to a more mobile society, ${ }^{6}$ where people might feel an attachment to a church with which they had some family connection, but not reside in that parish. Another more cynical explanation could be given. The Measure can be seen as the Church of England's response to the reforms effected by the Marriage Act 1994, which allows parties to contract civil marriages in a whole range of "approved premises ${ }^{, 7}$ which are more attractive and photogenic settings than the typical register office, and which may rival the more picturesque churches in this respect. This is often seen as a contributory factor in the recent drop in the proportion of marriages in religious buildings. ${ }^{8}$ It also obviates the need for the practice of someone who has moved away making a somewhat strained declaration of continued residence at her ${ }^{9}$ parents' home in order to be eligible to marry at a former 'home' church. The Church of England Measure does not, naturally enough, extend to the Church in Wales, and the MWA 2010 is its own response to similar trends.

\section{MARRIAGE LAWS IN WALES AND THE CONTINUED 'ESTABLISHMENT’}

The MWA 2010 is of particular interest for those interested in the question of the Establishment, as it is a 'textbook' example of a paradox of disestablishment: a disestablished church can rarely, if ever, ${ }^{10}$ enjoy the same legal status as church which has never been established (referred to here as a 'non-established church'), as it will always be bound by the terms of the statute by which it was disestablished, and any reforms involving a change to those terms will require further

(church) electoral roll of the parish: MA 1949, s 72. (The corresponding provisions in Wales are noted later in this article: see $\mathrm{n} 83$ and text thereto).

${ }^{6}$ See < http://www.cofe.anglican.org/info/socialpublic/marriagefamily/marriageanddivorce/marriagemeasure/ > accessed 29 Jun 2010.

${ }^{7}$ Such as hotels, stately homes and historic buildings.

${ }^{8}$ The number of marriages solemnised in religious buildings (including those that are solemnised other than in buildings of the Church of England and Church in Wales) has dropped by a quarter since 1998; the number of marriages overall has dropped in the same period by 13\%. Since the beginning of 2005 there have been more civil marriages in 'approved premises' than religious marriages. (Office for National Statistics: Marriages in England and Wales 2008 (published 11 Feb 2010: < http://www.statistics.gov.uk/pdfdir/marr0210.pdf > accessed 29 Jun 2010.).

${ }^{9}$ As will usually, but not always, be the case.

${ }^{10}$ One perhaps ought not to be too dogmatic here: an extreme provision by which a State simply appropriated all religious property would clearly leave its believers with the status of an entirely voluntary association, if indeed they were allowed to associate for religious purposes. 
primary legislation. One speaks of 'established' and 'non-established' churches; but the disestablished church will inevitably occupy a position between the two, and it will be difficult for a formerly established church ever to enjoy precisely the same status as a non-established church. The distinction is a well-known one ${ }^{11}$ but it is instructive to see a statute which so clearly demonstrates the principle. The fact that the Church in Wales is, in effect, an established church, insofar as the laws relating to marriage ${ }^{12}$ (and also to burial grounds) are concerned has been noted by Watkin. ${ }^{13}$

The paradox of the established Church of England being able to legislate reforms for itself, but her sister disestablished church needing to go to Parliament for this was noted during the debate in the House of Lords on the Second Reading of the Bill. Lord Bach ${ }^{14}$ explained the position in these terms: ' ... unlike the Church of England, which can pass its own rules, the Church in Wales cannot make legislative changes relating to its own administration and organisation. It therefore needs an Act of Parliament if it is to make such changes. ${ }^{, 15}$ Lord Henley expressed his surprise that this should be the case and that legislation should be coming before the House when the Church in Wales was disestablished. ${ }^{16}$ The Bishop of Salisbury explained the need for legislation thus: 'the Marriage Act has always stood independently of any ecclesiastical disciplinary matters. Therefore, because it is the law of the land, even when the Church in Wales was disestablished, it could not control it. ${ }^{17}$

Whilst it will serve as a general explanation, this proposition does require further exploration. At first sight, one may observe that the Welsh Church Act was passed in $1914,{ }^{18}$ and the principal Marriage Act currently in force is that passed in 1949. It therefore appears that, in 1949 - and on subsequent occasions when changes have been made to the legislative provisions on marriage - Parliament did not grasp the nettle and work through the implications of the

\footnotetext{
${ }^{11}$ It was noted, for example, by E Garth Moore in An introduction to Canon Law, (first edition, Oxford, 1967), p 15. Roger L Brown in 'The disestablishment of the Church in Wales', (1999) 5 Ecc LJ 252, p 254, is right to note that the Church in Wales was, in a sense, 're-established' by the Welsh Church Act 1914 (WCA 1914), though ìt is difficult to agree with him that CAH Green (Archbishop of Wales 1934-44) goes quite as far as this in The Setting of the Constitution of the Church in Wales (London, 1937), p 298.

${ }^{12}$ As to the law of marriage so far as it relates to the Church of England, see M Hill Ecclesiastical Law (third edition, Oxford, 2007), 5.31-5.49; RDH Bursell, Liturgy, order and the law (Oxford, 1996), ch 7, pp 157-198.

${ }^{13}$ Thomas Glyn Watkin 'Vestiges of Establishment - the ecclesiastical and canon law of the Church in Wales' (1990) 2 Ecc LJ 110; and see also 'Disestablishment, self determination and constitutional development of the Church in Wales' in N Doe (ed), Essays in Canon Law (Cardiff, 1992) 25 at 33ff.

${ }^{14}$ Parliamentary Under-Secretary of State, Ministry of Justice.

${ }^{15}$ HL Deb vol 715 col 1293 (11 Dec 2009). The statement is accurate as regards the legal rules of the State on marriage, but is surely too broad as it stands.

${ }^{16}$ Ibid, col 1292.

${ }^{17}$ Ibid, col 1293.

${ }^{18}$ For a good brief general account, see Brown, 'Disestablishment', 252-264.
} 
Church in Wales being disestablished, but preferred to take the easier course of allowing, in effect, the marriage law applicable to the established Church of England to continue to apply equally in the disestablished Church in Wales. This observation is not, however, wholly accurate, as the Marriage Act 1949 was a consolidating act, and its provisions with regard to marriages in the Church of England have much earlier origins. The Marriage Act of 1949 does make provision for marriages to be solemnised in the places of worship of non-established religious bodies in England and Wales, as did earlier acts: ${ }^{19}$ however, as it was a consolidating measure, it continued to treat the Church in Wales for the purposes of the marriage law as if it were still an established church. What is perhaps more surprising is that it preserved certain divergences between the marriage law of the Church of England, and that applicable within the Church in Wales, which had arisen between 1920 and 1949, as a result of the ability of the Church of England to legislate for its marriage law by Measure. ${ }^{20}$ These will be discussed later in this article.

\section{THE EVOLUTION OF THE PROVISIONS FOR MARRIAGE ON DISESTABLISHMENT}

Bearing in mind the highly partisan nature of the struggle for disestablishment of the Church in Wales, ${ }^{21}$ it is perhaps surprising that the anomaly of the continued establishment of the marriage law should have been allowed to persist. It is worth noting that, as noted by Watkin, ${ }^{22}$ if the Welsh Church Act 1914 had taken effect as originally enacted, the Church would have been placed on an equal footing as the non-established churches, and this anomaly would never have arisen. He does, however, oversimplify the position by going back only as far as the 1914 Act as passed. Strangely enough for the present discussion, the original clause relating to marriage in the Established Church (Wales) Bill of $1912,{ }^{23}$ then numbered 22, would have retained in Wales

\footnotetext{
${ }^{19}$ Going back as far as the Marriage Act 1836, which introduced both civil marriage (by the superintendent registrar in the presence of a registrar) (s 21), and marriages in 'registered buildings' (s 18) in the presence of a registrar (s 20). The Nonconformist and Roman Catholic churches could thus avail themselves of the latter provisions. The Marriage Act 1898 provided for a marriage to be solemnised in the presence of an 'authorised person' i.e. a person authorised by the trustees or governing body of a registered building: such an 'authorised person' might be the minister, or a member of the congregation. After the 1898 Act, therefore, religious marriages could be solemnised in non-Anglican places of worship without the attendance of someone from outside the congregation to represent the State. The MA 1949 preserved this general scheme, which operates via the concepts of the registered building (MA 1949, s 41) and the authorised person (MA 1949, s 43), rather than by making provision for particular denominations.

${ }^{20}$ Under the Church of England Assembly (Powers) Act 1919.

${ }^{21}$ Brown, 'Disestablishment', 252-264; for more detailed accounts, see Kenneth O Morgan, Wales in British Politics 1868-1922 (first edition, Cardiff, 1963); Kenneth O Morgan, Freedom or Sacrilige? (Cardiff, 1966); and PMH Bell, Disestablishment in Ireland and Wales (London, 1969), chs 7-8.

${ }^{22}$ Watkin, 'Vestiges of Establishment', p 112.

23 'the 1912 Bill'.
} 
the marriage law of the Church of England and thus it approximated to the present position. It ran:

Nothing in this Act shall affect the law with respect to marriage in Wales or Monmouthshire, or the right of a bishop of the Church in Wales to license churches for the solemnization of marriage or to grant licences to marry. Provided that where neither party to a marriage is a member of the Church in Wales they shall not be entitled as of right to have the marriage solemnized in a Church of the Church in Wales. $^{24}$

It is worth considering the reasons for the changes from the original 1912 Bill to the 1914 Act, as some of the objections to the 1912 position (i.e. the continued establishment of the marriage law) retain their validity even today.

Under the 1912 Bill, the question of who was a member of the Church in Wales would have been a matter for the Church to decide, ${ }^{25}$ though if a definition were to be agreed, then it could have been incorporated in the Act. ${ }^{26}$ The Church in Wales would, however, have been free to decide which, if any, non-members it would have been prepared to marry, and to regulate the matter by canon. This would, therefore, have enabled the Church to overcome what Watkin describes in his article as the 'vexed question' of how far the Church in Wales is obligated to marry those who are not communicant members of the Church, and, in particular, those who have not been baptised. At the time, however, this prospect seems not to have been on the agenda: a particular sticking point was the "perennial blister' 27 of whether the clergy should solemnise the marriage of a man with his deceased wife's sister. An amendment was proposed ${ }^{28}$ to repeal the Deceased Wife's Sister's Marriage Act 1907 in Wales insofar as it required the clergy of the Church in Wales to administer the sacraments to those who had taken advantage of the Act until

\footnotetext{
${ }^{24}$ HC Deb vol 47 col 113 (20 Jan 1913).

${ }^{25}$ HC Deb vol 38 col 361 (7 May 1912) (WA by Mr McKenna to Mr Ormsby-Gore). The Constitution of the Church in Wales $(C C W)(\mathrm{Ch} \mathrm{I,} \mathrm{Pt} \mathrm{II,} \mathrm{s} \mathrm{7)} \mathrm{currently} \mathrm{defines} \mathrm{a} \mathrm{member} \mathrm{as} \mathrm{'any} \mathrm{person} \mathrm{whose} \mathrm{name} \mathrm{is} \mathrm{entered} \mathrm{on} \mathrm{the} \mathrm{electoral}$ roll of a parish' (in addition 'member' includes 'office holders', members of the Governing Body and the Representative Body and their committees, and Clerics and deaconesses who are in receipt of a pension from the Representative Body).

${ }^{26}$ HC Deb vol 45 col 69 (9 Dec 1912) (WA by Mr McKenna to Mr Ormsby-Gore).

27 'He shall prick that annual blister, Marriage with deceased wife's sister' per the Queen of the Fairies in Iolanthe: WS Gilbert, The Savoy Operas (London, 1932), p 231. The 'blister' had eventually been pricked only 5 years previously by the Deceased Wife's Sister's Marriage Act 1907.

${ }^{28}$ HC Deb vol 47 col 116 (20 Jan 1913) (Mr Malcolm).
} 
the bishops so decreed. ${ }^{29}$ The amendment was withdrawn, ${ }^{30}$ and the House of Commons then went on to debate an amendment from $\mathrm{Mr}$ Hoare $^{31}$ to omit all references in the 1912 Bill to the marriage laws in Wales. The most interesting point to emerge from this debate, however, is that Lord Hugh Cecil, MP, ${ }^{32}$ a prominent spokesman for the Church, clearly took the view ${ }^{33}$ that, if the Church in Wales were to be disestablished, then it would be only fair that it should have the full benefit thereof in that it should have complete control over whose marriages it would solemnise in its churches. This, however, brought it into conflict with the principle that parishioners, regardless of denominational allegiance, at common law had the right to get married in the churches in Wales, and that church buildings were to be transferred to the new Church subject to all existing rights. ${ }^{34}$

The opposition, further, made a number of points, all of which, it must be admitted, still hold good today:

(a) the ordinary marriage law of the Church of England, both after the calling of banns and by common licence, was based upon the existence of parishes, and, after disestablishment, there would be nothing to stop the Church in Wales from amending its parish boundaries or abolishing them altogether. ${ }^{35}$

(b) marriage by (common) licence depended upon the existence of a licence granted under the seal of the chancellor or his surrogate, and yet the bill proposed abolishing all Church courts, and depriving Welsh Canon Law of the force of law. ${ }^{36}$

(c) Special Licences for marriage could be granted only by the Archbishop of Canterbury. ${ }^{37}$

\footnotetext{
${ }^{29}$ The amendment was prompted by the recent decision of the House of Lords in Thompson v. Dibdin, [1912] AC 533. Although the 1907 Act had permitted a clergyman on grounds of conscience to refuse to solemnise the marriage of a man with his deceased wife's sister, the case held that he could not decline to admit to Holy Communion as 'notorious evil livers' a couple who had contracted such a marriage.

${ }^{30}$ HC Deb vol 47 col 141 (20 Jan 1913).

31 Ibid.

${ }^{32}$ Youngest son of the $3^{\text {rd }}$ Marquess of Salisbury, and MP for Oxford University from 1910.

${ }^{33}$ This is clear from the exchange at HC Deb vol 47 col 124 (20 Jan 1913):

'Lord Hugh Cecil: The Church would a great deal prefer to be placed in the position of a Nonconformist body, and to be subject to the same conditions in regard to marriages if on those terms she had complete liberty to her own services.

Mr Llewellyn Williams: Even the presence of the registrar?

Lord Hugh Cecil: Certainly; why not? If the Church is to be Disestablished let it be Disestablished.'

${ }^{34}$ A point made by the Home Secretary, ibid, col 122.

${ }^{35}$ This point was made by Mr Hoare (ibid, col 142) and by Mr Cave (ibid, col 148). It cannot be argued that a parish structure is an indispensable part of Anglicanism. Although the Church of Ireland had retained and does still retain a parish structure, the Episcopal Church of Scotland retains territorial dioceses, but not parishes. For discussion of the parochial system in Wales, see Brown, 'Disestablishment', p 28.

${ }^{36}$ HC Deb vol 47 col 141 (20 Jan 1913).

${ }^{37}$ Ibid, col 144 (Mr Hoare).
} 
Mr Cave was in effect arguing that to continue the establishment quoad the law of marriage in Wales presented too many anomalies, which might call into question the independence of the Church; and it might therefore be better to treat the Church in Wales as a non-established church, governed by the Marriage Act 1898. He was particularly keen to avoid the confusion which arose after the Irish Church Act $1869,{ }^{38}$ which had left the law in Ireland on marriage in such an uncertain state that it had been necessary the following year to bring in further legislation. ${ }^{39}$ The upshot of the debate at the Committee Stage was that Mr McKenna, the Home Secretary, undertook $^{40}$ to withdraw clause 22 at the Report Stage if it was clear that that was what the church wanted, but that, if that was the case, it would be necessary to make it quite clear that the 1898 Marriage Act would apply to marriages in the Church in Wales.

Mr McKenna complied with his undertaking, and the clause that became section $23^{41}$ of the Welsh Church Act 1914 was introduced into the 1912 Bill at the Report Stage ${ }^{42}$ in substitution for

\footnotetext{
${ }^{38}$ Section 21 had provided 'the ecclesiastical law of Ireland, except in so far as relates to matrimonial causes and matters, shall cease to exist as law.'

${ }^{39}$ The Matrimonial Causes and Marriage Law (Ireland) Amendment Act 1870, which ran to forty-two sections and two schedules. The law of marriage in Ireland was historically distinct from that prevailing in England and Wales and is of some complexity. According to A J Shatter, Family Law (fourth edition, Dublin, 1997), prior to $R v$ Millis (1844) $10 \mathrm{Cl} \& \mathrm{~F}$ 534; 8 ER 844 (followed in Beamish v Beamish (1861) 9 HL Cas 274; 11 ER 735) it was assumed that the law of marriage in Ireland followed the common law as it was before the Reformation, accepting sponsalia per verba de praesenti, sponsillia [sic] per verba de futuro et copula, as well as marriage in facie ecclesiae (4.11). $R$ $v$ Millis, however, suggested that only marriages in the presence of an episcopally ordained clergyman - whether Roman Catholic or Episcopalian - were valid. In response to this, Parliament passed the Marriage (Ireland) Act 1844; it made special provisions for the various Presbyterian Churches (ss 4-11) (who were more numerous than Episcopalians in the northern counties), but specifically did not affect the existing law on Roman Catholic marriages (s 3). (As the Roman Catholic Church was complying with the requirements of the Council of Trent (1563), which required marriage to be in the presence of a priest and two witnesses, the requirements of the Roman Catholic canon law were more onerous than those of the common law). In addition the 1844 Act followed the Marriage Act of 1836 (see n 19) (which related to England and Wales), in that it provided for marriage in 'registered buildings' (s 27), so as to permit marriage in the places of worship of the smaller Protestant denominations, and also for civil marriage before the registrar (s 30). Roman Catholic marriage in Ireland continued after 1844 (and apparently still continues: see Shatter, 4.19-4.25) to be virtually unaffected by State law, save that the Registration of Marriages (Ireland) Act 1863 (ss 11, 14) required their civil registration. The 1870 Act principally established a Court for Matrimonial Causes and Matters (ss 5-31) to hear suits which would hitherto have been heard in the Irish Ecclesiastical Courts, but it also made certain provisions (ss 32-36) respecting the marriage of 'Protestant Episcopalians' consequent upon the disestablishment of the Church of Ireland. After 1870, therefore, there continued to be a 'quasi-establishment' of the three principal denominations (Roman Catholic, Church of Ireland, and Presbyterianism) in respect of the marriage laws, and in addition 'other' religious marriages, and civil marriages.

${ }^{40} \mathrm{HC}$ Deb vol 47 col 151 (20 Jan 1913); and again at cols 165-166.

41 'As from the date of disestablishment, the law relating to marriage in churches of the Church of England (including any law conferring any right to be married in such a church) shall cease to be in force in Wales and Monmouthshire, and the provisions of the Marriage Acts 1811 to 1898 relating to marriages in registered buildings shall apply to marriages in Churches of the Church in Wales, and every such church may accordingly be registered under and subject to the conditions imposed by those Acts.

Provided that: (a) [proviso for registration of existing churches without fee]; (b) A person who at the date of disestablishment is the incumbent of any parochial benefice in Wales or Monmouthshire shall, on making application to the Registrar-General for the purpose, be entitled to be appointed as the authorised person with respect to all churches within his spiritual charge as such incumbent which by virtue of this section become registered buildings.' ${ }^{42}$ HC Deb vol 47 col 1884 (3 Feb 1913); the clause was read a second time, and added to the bill.
} 
the previous clause discussed above. The only inference to be drawn from fact that there was no discussion on the new clause, either at Report Stage or on Third Reading ${ }^{43}$ is that having a wholly disestablished marriage law had by early 1913 become, so far as the Church and its supporters were concerned, the preferred option - or at least its 'least worst' option.

The operation of the Welsh Church Act 1914 was suspended ${ }^{44}$ on the outbreak of the First World War until hostilities were ended, but the Welsh Church Commissioners ${ }^{45}$ continued to prepare for disestablishment and disendowment; and the Church within Wales continued to organise itself to meet these events. ${ }^{46}$ Financial difficulties encountered by the Welsh Church Commissioners in effecting disendowment ${ }^{47}$ led to the introduction of the Welsh Church (Temporalities) Bill of $1919 .{ }^{48}$ Although dealing chiefly with these financial matters, the bill included as its Clause 6:

Nothing in this Act or in the Welsh Church Act 1914 shall affect -

(a) the solemnisation of any marriage according to the rites of the Church of England in Wales after the publication of banns in the manner customary before Disestablishment; or

(b) the right of the bishops of the Church in Wales to license churches for the solemnisation of marriages or to grant licences to marry. ${ }^{49}$

The explanations given for inserting this clause are contradictory and confusing. At the Second Reading of the 1919 Bill the Home Secretary, Mr Shortt, explained that it mainly dealt with the financial details of disendowment,${ }^{50}$ but added that amendments to the provisions on

\footnotetext{
${ }^{43}$ Ibid, cols 2231-2237 (5 Feb 1913). Although the bill was debated in the following two sessions, before being presented for Royal Assent under the terms of the Parliament Act 1911, the subsequent debates were confined to the general principles involved. To comply with the terms of the 1911 Act the bill would have to be passed in substantially identical terms as in its first passage, so there was no opportunity to debate or reconsider amendments.

${ }^{44}$ By the Suspensory Act 1914.

${ }^{45}$ Officially, the 'Commissioners of Church Temporalities in Wales' who were established by the WCA 1914 , s 10.

${ }^{46}$ See Brown, 'Disestablishment', p 262; Morgan, Wales in British Politics, p 279; Bell, Disestablishment in Ireland and Wales, pp 299-308.

${ }^{47}$ Details are to be found in Brown, 'Disestablishment', p 262; Morgan, Wales in British Politics, pp 286-290; Bell, Disestablishment in Ireland and Wales, pp 311-315.

48 'the 1919 Bill'.

${ }^{49}$ HC Deb vol 119 col 1061 (11 Aug 1919).

${ }^{50}$ Shortt can perhaps be excused some lack of familiarity with the Bill. The term of office of the Welsh Church Commissioners was due to expire on 31 December 1919, their work had not been completed, and an Amending Bill was clearly required to deal with difficulties in the process of disendowment. The details of the Bill were worked out between Lloyd George and the Welsh bishops, and on 24 July 1919 the bishops were told that a draft Bill was needed within 48 hours. They arranged for it to be privately drafted and submitted to the Government (see Morgan, Wales in
} 
marriage would also be required: the specific example that he gave implied that only a minor amendment would be required, ${ }^{51}$ and did not adumbrate the major change which would in fact be made.

When the new clause came up for debate at the Committee stage, Mr Shortt said that this clause had been originally included in the bill at the request of the Church in Wales, apparently as part of a desire to retain traditional Anglican marriage practice as a matter of internal Church discipline: it would not have affected the position under the (civil) marriage law, which would have been identical to that which applied in the Nonconformist churches, under the Marriage Act 1898. But, by the time of the debate, it would seem that the Registrar-General had objected that the clause could not stand alongside section 23 of the Welsh Church Act $1914,{ }^{52}$ presumably on the grounds that it would cause confusion as to the procedure on marriage in churches of the Church in Wales: banns or an (ordinary) licence would be required under the canon law, but not under the civil law of marriage, which would require a superintendent registrar's certificate. $\mathrm{Mr}$ Shortt, therefore proposed an amendment to the clause, ${ }^{53}$ so that it read instead:

Nothing in this Act or in the Welsh Church Act 1914 shall affect -

(a) the law with respect to marriages in Wales and Monmouthshire; or

(b) the right of the bishops of the Church in Wales to license churches for the solemnisation of marriages or to grant licences to marry; and section 23 of the Welsh Church Act 1914 is hereby repealed.

This was therefore in effect reverting to the proposal originally made in the 1912 Bill, though, whether by accident or design, the proviso where neither party was a member of the Church in Wales was omitted. ${ }^{54}$ The explanations given by Mr Shortt for the amendment ${ }^{55}$ are somewhat garbled. He mentioned that originally in 1912 it had been intended to leave the

\footnotetext{
British Politics, p 287; Bell, Disestablishment in Ireland and Wales, p 309; Eluned E Owen, The Later Life of Bishop Owen (Llandyssul, 1961), pp 401-421. Shortt was left in ignorance of the details.

${ }^{51}$ HC Deb vol 119 col 466 (6 Aug 1919): 'I think, with regard to all the other matters, that they are really domestic matters. For instance, in the case of marriage, owing to the wording of the Act of 1914, in a large parish with four or five curates the vicar would be the only one able to solemnise marriage, and provision is made by the Bill so that the curates may do so'. This would imply that only a minor amendment to proviso (b) to the WCA 1914, s 23 (see n 41) would be required. Clause 6 in the published bill clearly did not and could not resolve the difficulty outlined.

${ }^{52}$ HC Deb vol 119 cols 1061-1066 (11 Aug 1919).

53 Ibid.

${ }^{54}$ See notes 24 to 26 and text thereto.

${ }^{55}$ Although technically Clause 6 was amended, it should be noted that it was originally intended only to declare the permissibility of the traditional marriage service and its preliminaries, even though it would also be necessary to
} 
marriage law in Wales as it stood, but then an attempt had been made by Sir George Cave to assimilate the position in Wales to that in the Irish Church Act 1869. That had been found to be impossible, so it had been decided to revert to the position originally proposed. ${ }^{56}$ This does not very accurately represent the debate of 20 January $1913:{ }^{57}$ In particular Sir George Cave (then $\mathrm{Mr}$ Cave) had been keen to avoid the confusion that had resulted from the Irish Church Act and had required further legislation. There was no debate on the amendment to Clause 6 in 1919: it is curious that a provision which had caused such dissension in 1912 was simply nodded through. It may be that, with the principle of disestablishment having been accepted, the protagonists for the established church had lost the will to fight over such points of detail. The political complexion of the Government and of the House had changed since 1912-1914, as by 1919 former political opponents were on the same side of the house as Coalition Unionists and Coalition Liberals. ${ }^{58}$ Further, it was generally accepted that the terms of the Welsh Church (Temporalities) Bill 1919 greatly sugared the pill of disendowment. ${ }^{59}$

Again, in spite of the presence of the Bishops, there was no discussion of the change of policy on the marriage law when the 1919 Bill was debated in the House of Lords. ${ }^{60}$

The tone of the account of the events of 1912-1919 given by Archbishop Green in $1937^{61}$ suggests that by this time he, at least, broadly approved that 'to this extent the State continues to protect the Church and to confirm her acts.' He makes no mention of the objections made in 1912-1914 on behalf of the Church to the continued establishment of the marriage laws.

\section{THE INCONSISTENCIES OF THE ESTABLISHMENT OF THE MARRIAGE LAWS}

Nonetheless, the reinstatement of the position under the 1912 Bill means that the inconsistencies identified then - resulting from the preservation of an established law of marriage ${ }^{62}$ within a

\footnotetext{
comply with the formalities of the Marriage Act 1898; after amendment it marked a complete reversal of policy from the 1914 Act.

${ }^{56}$ HC Deb vol 119 col 1061 (11 Aug 1919).

57 See notes 27 to 40 and text thereto.

${ }^{58}$ A vote was taken on the Second Reading, but the only opponents to the provisions of the Amending Bill were by then thirty-two Unionists (those among the party who remained diehard opponents of disestablishment), three Welsh Liberals sitting for rural seats (who claimed that it was re-endowing the Church in Wales at public expense) and two Labour members (Morgan, Wales in British Politics, p 290).

${ }^{59}$ See Bell, Disestablishment in Ireland and Wales, pp 311-315 ; Morgan, Wales in British Politics, pp $286-290$.

${ }^{60}$ HL Deb vol 36 cols 882-921 (14 Aug 1919) (Second Reading); ibid, cols 951-973 (15 Aug 1919) (Committee and Third Reading).

${ }^{61}$ Green, Constitution of the Church in Wales, pp 310-311.

62 That there has been no change to the established marriage law in Wales is confirmed by the case of Powell $v$ Representative Body of the Church in Wales [1957] 1 WLR 439, in which Wynn-Parry J confirmed that the ancient right of the Rector of Hawarden to issue, concurrently with the Bishop, marriage licences within the historic parish of
} 
disestablished church -remained true in 1919, and remain true today. Chiefly one might identify the following:

(a) the possibility that, in Wales, those who are not baptised have the same legal right to marry in their parish church as do those in England - indeed, the point was conceded by a spokesman for the Church in Wales ${ }^{63}$ in his evidence to the 1935 Commission on Church and State. ${ }^{64}$ The probable inability of the Church of England to determine whom it will marry ${ }^{65}$ is a bone of contention in England, and the present writer does not propose to enter into that debate. Suffice it to say that if it is not acceptable to the established Church of England, it is surely more of an injustice for the disestablished Church in Wales. The matter is discussed by Watkin. ${ }^{66}$ Setting this point to one side, the requirement to solemnise the marriages of those who are not in membership of the Church in Wales - in the sense of being on the electoral roll of a parish - but who are baptised (including Christians of other denominations) has not apparently presented any particular difficulty for the Church.

(b) The ordinary marriage law, in Wales, as in England, and whether marriage is after the calling of banns or by ordinary licence, is based on the existence of a parochial system, and the Church in Wales can alter its own parochial boundaries, ${ }^{67}$ so affecting the rights of nonmembers to get married in a particular church. ${ }^{68}$ Further, it could, in theory at least, follow the Scottish Episcopal Church ${ }^{69}$ and dispense with an organisation based upon parishes.

Hawarden, had not been affected by the WCA 1914, as amended by the Welsh Church (Temporalities) Act, 1919. The fact that the rectorship was no longer a corporation sole was held not to be relevant.

${ }^{63} \mathrm{Mr}$ Frank Morgan, Honorary Secretary to the Representative Body and to the Governing Body of the Church in Wales.

${ }^{64}$ Report of the Archbishops' Commission on the Relations between Church and State, (2 vols, Westminster, 1935), vol II, p145.

${ }^{65}$ This is a contentious topic which has already been widely discussed. That the right exists in these terms is broadly accepted by Bursell, Liturgy, order and the law at p 183, and by Hill Ecclesiastical Law at 5.34, though in fn 126 he notes the argument to the contrary of N Doe in Legal Framework of the Church of England (Oxford, 1996) at 358362, and of M Smith in 'An Interpretation of Argar v. Holdsworth' (1998) 5 Ecc LJ 34, and the supporting view of J Humphreys in 'The Right to Marry in Church: a Rehabilitation of Argar v. Holdsworth (2004) 7 Ecc LJ 405. The latest (eighth) edition of Legal Opinions concerning the Church of England (London, 2007)('Marriage: right of parishioner to marry in parish church') pp 376-382 considers Doe's view but affirms the traditional view expressed by Hill and Bursell. Clearly if the 'Right to Marry' does not in fact exist in England, then it cannot exist in Wales. ${ }^{66}$ Watkin, 'Vestiges of Establishment', p 113. The Book of Common Prayer of the Church in Wales (1984) 736 clearly states the position of the church on this: 'Christian marriage is marriage between two baptized persons', and states that, in other cases, the 'Minister shall act in accordance with the Bishop's direction'. In The law of the Church in Wales (Cardiff, 2002) N Doe suggests that, given the 'powerful legal fiction' ( $\mathrm{p} 257$ ) of the 'Right to marry', the Bishop would have little alternative but to direct the minister to solemnise the marriage (p 258, n 26).

${ }^{67}$ The procedure is set out in the $C C W$, ch IV D, s 3. The Bishop's Decree must make provision for marriages (ibid, s 4).

${ }^{68}$ The Constitution and Canons of the Church in Wales operate as a civil contract only between the members of the Church in Wales (WCA 1914, s 3(2), and CCW, ch I, pt I, s 2. Ch I, pt II, s 7 defines 'member' principally by reference to the electoral rolls kept by each parish (see $\mathrm{n} 25$ ).

${ }^{69}$ See n 35. 
(c) The bishops of the Church in Wales still license churches for marriages, and may issue licences for marriage; in practice common licences are issued by a surrogate or the Diocesan Registry. Further, the Constitution of the Church in Wales makes provision for the diocesan chancellor to continue to exercise jurisdiction over marriage licences. ${ }^{70}$ The courts of the Church in Wales thus remain involved in the marriage law. Although these courts are, at diocesan level, broadly similar to those operating in England, ${ }^{71}$ they are, in law, internal tribunals $^{72}$ of a voluntary body rather than part of the Queen's courts. ${ }^{73}$

(d) The fact that Special Licences for marriage within the Church in Wales are still granted by the Faculty Office of the Archbishop of Canterbury. ${ }^{74}$

Notwithstanding the prognostications of MPs such as Lord Hugh Cecil, Mr Hoare, and Mr Cave in 1912, the fact that the inherent inconsistency of the marriage law of the Church in Wales has not caused problems to materialise in the ninety years of its existence suggests that it is unlikely now to do so. That it has not caused problems can perhaps best be attributed to a measure of conservatism in the Church in Wales. At disestablishment it preferred to carry on very much as before, and did not seek to make any more changes in its organisation than were

\footnotetext{
${ }^{70} \mathrm{CCW}$, ch IX, s 30: 'Each Chancellor, with respect to the granting of marriage licences and the appointment of surrogates, shall in addition to any jurisdiction or powers conferred on him or her by the Constitution, have the jurisdiction and powers (except as to fees) to which a Chancellor was entitled on $30^{\text {th }}$ March 1920, and shall exercise such jurisdiction and powers according to the law and practice at that time prevailing.' This is an interesting example of the 'fossilisation' of the law relating to those aspects of the Church in Wales which remain established. One would assume that the issuing of common licences (generally in practice through surrogates) is likely to be one of the most frequent exercises of the chancellor's jurisdiction, though it seems unlikely, however, that occasion would often arise for the exercise any kind of contentious jurisdiction.

${ }^{71}$ Each diocese has a court presided over by a chancellor, which is however termed the 'Diocesan Court' rather than the 'Consistory Court'.

72 WCA 1914, s 3(3). For a discussion of the system of Church courts in Wales, and its shortcomings, see Thomas Glyn Watkin, 'Welsh Church courts and the rule of law', (2000) 5 Ecc LJ 460.

73 'He [sc. the Chancellor] is a Queen's judge, in one of the Queen's courts' (Halsbury's Laws, vol 14, 4th edition (London, 1975) at para 1275).

${ }^{74}$ MA 1949, s 5(b). This is not one of the sections of the MA 1949 that does not apply in Wales: see Sch 6. The continued jurisdiction to issue Special Licences in Wales can be explained by the fact that the jurisdiction to issue Special Licences lies with the Archbishop of Canterbury not by virtue of his authority as Archbishop and Metropolitan of the Province of Canterbury but because the powers of the Papal Legate were transferred to his office by the Ecclesiastical Licences Act 1533: for this reason his power to issue Special Licences also extends to the Province of York. Legatine powers which did not relate to marriage were not allowed to continue, at least insofar as they were to apply wholly within Wales. This had the slightly anomalous result that power to grant faculties for the appointment of notaries public, which was also one of the legatine powers, was exercised by the Archbishop of Canterbury throughout England and Wales, but on disestablishment, the power to appoint district notaries within districts situated wholly in Wales was transferred to the Lord Chancellor (WCA 1914, s 37). The power to appoint general notaries (i.e. those having jurisdiction throughout England and Wales) remained with the Archbishop of Canterbury, even if the notary's principal place of business was in Wales. No new district notaries can be appointed since the passing of the Courts and Legal Services Act 1990 (s 57(1)), so the WCA 1914, s 37, ceased to have effect (s 57(3)(e) CLSA 1990) and the Faculty Office of the Archbishop of Canterbury again is the only authority appointing notaries in Wales, as all such appointments are effective throughout England and Wales.
} 
necessitated by its change of status. ${ }^{75}$ The idea of abandoning the parochial system was never on its agenda: indeed, the principle of maintaining a ministry to all has been preserved notwithstanding disestablishment. ${ }^{76}$ Similarly, the Church in Wales has been content to retain its traditional system of church courts which, at least at diocesan level, follows broadly the same pattern as the Church of England.

\section{DIVERGENCES BETWEEN THE MARRIAGE LAWS OF ENGLAND AND OF WALES}

As a result of the disestablishment settlement of the marriage law, the marriage laws of England and of Wales gradually grew out of step, in minor though significant details. The Marriage Measure 1930 permitted banns ${ }^{77}$ to be called, and for persons to be married, in a church of the Church of England if neither party resided in the parish, but one or both was on the church electoral roll of the parish. ${ }^{78}$ Four years later the Banns of Marriage Measure 1934 permitted laypersons to call the banns if conducting, with the permission of the bishop, a service in the absence of a clergyman. ${ }^{79}$ Neither of these Measures applied to Wales. ${ }^{80}$ These provisions were then consolidated in the Marriage Act $1949^{81}$ (but for England only ${ }^{82}$ ), and were not extended to

\footnotetext{
75 In Roger Lee Brown, 'What of the Church in Wales?' (1993) 3 Ecc LJ 20, p 26, one of the sections of the article is headed, 'A national role for a disestablished church'.

${ }^{76}$ Ibid, p 28.

77 The Measure also provided (s 3) for marriage by common licence in a church where one of the parties was on the electoral roll of that church.

${ }^{78}$ Although this provision was enacted by Measure, when it came before the House of Commons for approval (under the provisions of the Church of England Assembly (Powers) Act 1919) one dissentient member (Dr Peters) argued that it was never intended that this enabling act would extend to changes in the marriage law (HC Deb vol $236 \mathrm{cols}$ 1656-1658 (13 March 1930)). The Forty-first Report by the Ecclesiastical Committee, being a Report on the Marriage Measure, 1930 ((1929-30) Parl Papers viii 92), raised no objection, and simply recommended that it was 'expedient that it should proceed', but Dr Peters may have had a point. Although Halsbury's Statutes and Halsbury's Laws, both on-line and in hard copy, cross-reference to Measures of the General Synod, Current Law Statutes do not provide an annotated edition of the Marriage Measure 2008, though they will no doubt do so for the Marriage (Wales) Act 2010! The Canons of the Church of England do not supplement the legislative provisions, save that Canon B 35 (at paras 1 and 2) requires compliance with the general law, and (at paras 3 and 4) repeats certain provisions of it.

${ }^{79}$ It also provided for the banns to be called by a clergyman at a service other than the usual one at which banns were called at that church. In setting out the functions of readers and lay workers, the Canons include the calling of banns (E4 para 2(b) (readers) and E7 para 5(c) (layworkers)).

${ }^{80}$ Both Measures were expressed to extend to 'the whole of the Provinces of Canterbury and York except the Channel Islands and the Isle of Man'. See further $n 95$.

${ }^{81}$ MA 1949, s 6(4) permits the calling of banns in a church which is the usual place of worship of either party, and section 12(1) then permits the solemnisation of marriage in any church where the banns have been called. Section 15(1)(b) permits a common licence to be granted for the solemnisation of marriage in a church which is the usual place of worship of either party. As with the Marriage Measure 1930, however, s 6(4) and s 15(1)(b) do not have the scope that they appear to have at first sight, as MA 1949, s 72 provides that "no parish church or authorised chapel shall be deemed to be the usual place of worship of any person unless he is enrolled on the church electoral roll of the area in which that church or chapel is situated'.

${ }^{82}$ Whilst in most of the MA 1949, a reference to the Church of England was deemed to include the Church in Wales (MA 1949, s 78(2)), by virtue of MA 1949, s 80(3) and the Sixth Schedule to the Act, ss 6(4) and 15(1)(b) did not apply to Wales. It was not therefore possible for parties in Wales to take advantage of s 12(1), allowing a marriage to
} 
Wales until the passing of the Marriage (Wales and Monmouthshire) Act $1962{ }^{83}$ This has the result that the (established) marriage law of Wales incorporates provisions that rely on the keeping of electoral rolls of the Church in Wales, which are themselves entirely a matter for its domestic membership rules. ${ }^{84}$ This is perhaps the least remarkable of the anomalies: any religious body which offers state-sanctioned religious marriage under the Marriage Acts may have its own rules as to whom it is prepared to marry in its registered buildings, and this extension of the availability of places wherein marriage might be solemnised within the Church in Wales was, ex hypothesi, available only to its own members.

What is surely of more interest is that reforms which took effect in England in 1930 and 1934 by the Church of England's own legislation ${ }^{85}$ did not take effect in Wales until 1962: this shows the significance of the continued establishment of the marriage laws, and, in particular, that the marriage law of the Church in Wales can get out of step with that which prevails within the Church of England. This had been pointed out as long ago as 1935 by the Church in Wales. ${ }^{86}$

There is also an especial irony in the situation that prevailed in Wales between 1930 and 1962. In England it had been recognised that a person might not owe his or her principal allegiance to his or her parish church, but in Wales - where church membership was to be based on a contract between the members ${ }^{87}$ - the principle of geographical attachment to a parish church still exclusively prevailed, to the extent that even persons who had indicated their allegiance to a church other than their own parish church by placing themselves on the electoral roll of that church might not be permitted to marry there, either after banns or by common licence.

There have been further examples of the marriage law in the Church in Wales falling out of step with the Church of England, and requiring legislation to bring the position in Wales in line

take place in any church where the banns had been called (whether or not the parties resided there), or for a common licence to be granted to permit solemnisation of marriage in a church which was the usual place of worship of either party.

83 There was no debate on the bill at Second or Third Reading. In Committee Mr George Thomas (later Viscount Tonypandy) explained (HC Deb 1961-62 (Standing Committee C) col 5 (28 March 1962)) that the purpose of the bill was to apply to Wales the provisions of the MA 1949 which did not apply to Wales as they had been derived from the Marriage Measure 1930 and the Banns of Marriage Measure 1934. Section 1 of the 1962 Act extended s 6(4) and other provisions of the MA 1949 to Wales, providing that references in the Act to 'electoral rolls' should extend to electoral rolls kept pursuant to the constitution and regulations of the Church in Wales. The 1962 Act also permitted the calling of banns by lay persons who might be taking a service.

${ }^{84}$ In England, of course, the rules governing the composition of Electoral Rolls are part of the establishment, and therefore ultimately 'part of the law of the land'.

${ }^{85}$ It was held in R. $v$ Archbishops of Canterbury and York, ex parte Williamson (The Times, 9 March 1994, CA) that a Measure is primary rather than delegated legislation: this is acknowledged in the Human Rights Act 1998, s 21(1). See further Hill, Ecclesiastical Law, 1.25, 1.30; Doe, The Legal Framework of the Church of England, pp 60-62.

${ }^{86}$ By its spokesman Mr Frank Morgan: see n 64 at p 141. 
with that which pertains in England. In one case this required amendment of the Canon Law of the Church in Wales; in the other, as with the MWA 2010, an Act of Parliament was required:

(1) When the Marriage (Extension of Hours) Act 1934 was passed, the Church in Wales had to promulgate a canon on the 'Extension of the Hours of Marriage in Church' ${ }^{88}$ amending canons 62 and 102 of the Canons of 1603, in order to ensure that the canon and civil laws in Wales did not diverge. Presumably if the canon had not been passed, a marriage in the Church in Wales solemnised between 3 pm and 6 pm would have been legal but uncanonical. $^{89}$

(2) the Marriage (Wales) Act 1986 was required in order to deal with the difficulties caused by the grouping of benefices; the problem had been addressed within the Church of England by section 23 of the Marriage Act 1949, which referred to the Pastoral Reorganisation Measure 1949, and had further been amended by the Pastoral Measure 1968 and the Pastoral Measure 1983.

More recently, there has been an example - it would seem a unique one - of Parliament intentionally ${ }^{90}$ differentiating between the Church of England and the Church in Wales when legislating on marriage law. The Gender Recognition Act 2004, whilst in general making provisions relating to marriage which apply throughout England and Wales, inserted ${ }^{91}$ a new section 5B in the Marriage Act 1949, which by subsection (1) gives any clergyman a right 'not to solemnise the marriage of a person if the clergyman reasonably believes that the person's gender has become the acquired gender under the Gender Recognition Act 2004, ${ }^{92}$ Subsection (2), however, then allows, on the same grounds, a Clerk in Holy Orders of the Church in Wales not to permit the marriage of such a person to be solemnised in the church or chapel of which he or she is the minister. Apparently the Church in Wales sought this exemption, but not the Church of

\footnotetext{
${ }^{87}$ See n 68.

${ }^{88}$ Canon passed 26 September 1935: Green, Constitution of the Church in Wales, p 261.

${ }^{89}$ On the basis that the marriage had been contracted in accordance with the law of the State, it could hardly have been invalid; but in theory the minister solemnising the marriage would have been acting in breach of canon law, and thus answerable in the Church courts (using 'canon law' here in the sense suggested by Watkin in 'Vestiges of Establishment').

90 The MA 1949 treated the countries of England and Wales differently, but did not differentiate between the Church of England and the Church in Wales per se (see $\mathrm{n} 95$, and text thereto). Further, it was, in any event a consolidating statute.

${ }^{91} \mathrm{~S} 11$, and sch 4, para 3

${ }^{92}$ RJ Ahdar and I Leigh Religious Freedom in the Liberal State (Oxford, 2005) state (at 358) of s 5B(1): 'Originally it was worded to provide an explicit exemption for ministers of the Church of England and Church in Wales - based on the premise that they were the only religious bodies legally required to conduct marriages.' (per Lord Filkin, HL Deb vol 656 col 1072 (10 Feb 2004)).
} 
England. ${ }^{93}$ Whilst one can understand why the Government wished to accommodate the Church in Wales in this respect, it creates an anomaly, when in other respects the marriage law of the Church in Wales so closely follows that of the Church of England.

Before concluding it is perhaps worth noting a minor point. This article has, for convenience, generally ${ }^{94}$ referred to the 'marriage law of England' and the 'marriage law of Wales' but this distinction is not quite true. It would more accurately refer to the "marriage law of the area of the Church of England' and the 'marriage law of the area covered by the Church in Wales' ${ }^{95}$ As Bell $^{96}$ and Brown ${ }^{97}$ remind us, at disestablishment the nineteen parishes which straddled the border between England and Wales were given the option by plebiscite ${ }^{98}$ of either staying within the Church of England or of joining the Church in Wales. Only one voted to join the Church in Wales. The result is that in several small areas of Wales near the border there is still an

\footnotetext{
${ }^{93}$ Per Mr D Lammy (Parliamentary Under-Secretary of State for Constitutional Affairs): 'The protection has been given to the Church in Wales, at its request, but the Church of England has said clearly that it does not want it.' (HC Deb 2003-04 (Standing Committee A) col 162 (16 March 2004))

${ }^{94}$ Apart from when discussing the Gender Recognition Act 2004.

${ }^{95}$ Note that this was not the case between the passing of the MA 1949 and the passing of the Marriage (Wales and Monmouthshire) Act 1962. By an apparent oversight, the disapplication in respect of Wales of certain provisions in the MA 1949 extended to the whole area of Wales (including Monmouthshire), and not to the area covered by the Church in Wales. This anomaly was not corrected until the passing of the 1962 Act (s 2). Prior to 1962, the references in the MA 1949 to the calling of banns in churches, and the disapplication of certain provisions to Wales (by sch 6) meant that, in border parishes, the applicable law depended on which side of the national boundary the parish church lay (HC Deb 1961-62 (Standing Committee C) cols 8-9 (28 March 1962) per Mr George Thomas). The MWA 2010, s 1, carefully states that it applies 'to parishes in the area subject to the Welsh Church Act 1914'. It was not stated in the Standing Committee what the position had been in the border parishes between 1930 and 1949. As the Marriage Measure 1930 extended to 'the whole of the Provinces of Canterbury and York except the Channel Islands and the Isle of Man' (s 9), as did the Banns of Marriage Measure 1934 (s 2), then both Measures must have applied to all those border parishes which were part of the Church of England, regardless of the location of the parish church, until the MA 1949 inadvertently re-aligned the 'marriage law' boundary to the national boundary.

${ }^{96}$ Bell, Disestablishment in Ireland and Wales, p 305.

${ }^{97}$ Brown, 'Disestablishment', p 252-253.

${ }^{98}$ This was provided for the WCA 1914, s 9. The plebiscites were conducted by the Welsh Church Commissioners. Bell, Disestablishment in Ireland and Wales, p 305, points out the punctilious way in which the commissioners went about their work, whilst noting the incongruity of holding these plebiscites at the height of the First World War. Ballot papers were sent to men serving in the Forces. (Second Report of the Commissioners for Church Temporalities in Wales (1917-18) Cd 8472 viii 93, p 4.). He is mistaken in stating that the 19 votes were conducted in March 1916. The First Report of the Commissioners for Church Temporalities in Wales (1914-16) Cd 8166, p 5 makes it clear that the polls were conducted in all the parishes in January/February 1915. The results in 17 of the parishes showed that there was a 'marked preponderance of opinion' in favour of remaining part of the Church of England, so that the Commissioners considered that they need take no further action. In the two remaining parishes - Llansilin and Rhydycroesau - they decided that they need to carry out a more precise ballot, and these were the ballots that were carried out in March 1916. Both the 1915 and 1916 ballots were on the basis that all inhabitants of the parish over the age of 21 , whether male or female, were entitled to vote; this was a broader franchise than that applicable for local government purposes under the Local Government Act 1894, and did not apply in parliamentary elections until the Equal Franchise Act 1928. (Were these pioneering examples of universal adult suffrage?) Non-resident ratepayers could also vote. The difficulties in conducting the ballot were exacerbated by the fact that there was no suitable electoral register. The return rate was a quite remarkable $85.5 \%$ in Llansilin, and $86.3 \%$ in Rhydycroesau (or an astonishing $97.2 \%$ and $96.6 \%$ respectively if one counts late and spoilt papers). Llansilin voted by 255 to 228 in favour of forming part of the Church in Wales, and Rhydycroesau by 98 to 78 in favour of remaining part of the Church of England.
} 
established church, and, perhaps more remarkably, in one very small area of England the Church has been disestablished. ${ }^{99}$ The applicable marriage law is determined by the boundary between the Churches, not by the national boundary. ${ }^{100}$ This complication would have to be addressed and perhaps even the line of the 'disestablishment boundary' redrawn - if ever the Welsh Assembly acquired competence over the marriage laws in Wales. ${ }^{101}$

\section{CONCLUSIONS}

The necessity for Parliament to have to pass the MWA 2010 is a nice illustration of the general point that a disestablished church can seldom if ever enjoy exactly the same status as a church which has never been established; and also of the more specific point that, in a very real sense, the Church in Wales remains established when it comes to its marriage law. ${ }^{102}$ This article has also drawn attention to the other occasions where, as a result of legislation - formerly by the Church Assembly and now by the General Synod - the marriage law applicable in England has been reformed, the law in Wales has accordingly got out of step, and it has required parliamentary legislation to amend the position in Wales. This could even be seen as questioning how appropriate it is for the Church of England to amend the law on marriage by Measure.

One could also note that, if one takes a strict view of such matters, the marriage law in Wales is inherently inconsistent, both in giving a disestablished church the privileges and burdens of establishment, and also in that the marriage law relies for its coherence on matters such as the parochial system and the system of church courts which are in Wales, to use Watkins's distinction, ${ }^{103}$ matters of canon law ${ }^{104}$ rather than the ecclesiastical law. ${ }^{105}$ In spite of the prognostications of the opponents of disestablishment in 1912, these theoretical difficulties have not, in 90 years, caused noticeable difficulties in practice. A case could be made on the grounds of consistency for further reform of the marriage law in Wales, but it seems likely to have to await any possible wholesale future reform of the marriage laws in England and Wales, either to require civil marriage as a prerequisite of any religious marriage, or the more conservative option

\footnotetext{
${ }^{99}$ And so the MWA 2010 applies to a small part of England as well as to Wales!

${ }^{100}$ See $\mathrm{n} 95$.

${ }^{101}$ Even if the Act-making powers of the Welsh Assembly under Part 4 of the Government of Wales Act 2006 should be implemented, registration of marriages would remain excepted from its legislative competence (sch 7, para 12). Marriage is, however, a devolved matter in Scotland (e.g. the Marriage (Scotland) Act 2002, asp 8).

${ }^{102}$ Watkin, 'Vestiges of Establishment', pp 111-113.

${ }^{103}$ Ibid, pp 110-111.

${ }^{104}$ I e matters for the internal or domestic law of a voluntary association.

${ }^{105}$ I e the law governing the established church.
} 
of standardising the law by requiring uniform civil preliminaries to marriage. ${ }^{106}$ Uniform civil preliminaries were also proposed by the consultation paper Civil Registration: Delivering Vital Change ${ }^{107}$ following which authorised celebrants would be entitled to conduct the marriage at any time or place. ${ }^{108}$

\footnotetext{
${ }^{106}$ As was proposed by the Law Commission, Report on the Solemnisation of Matrimony in England and Wales (Law Com No 53), (London, 1973), paras 17 and 23. The Commission noted that banns would no longer be required, unless the Church chose to retain them as an ecclesiastical requirement (paras 18, 19 and 23). This is the solution which was in 1919 held to be impracticable when to be applicable in Wales only (see text to $\mathrm{n} 52$ ).

${ }_{107}$ Office for National Statistics, 2003.

${ }^{108}$ See R Probert 'Lord Hardwicke's Marriage Act - Vital change 250 years on?' [2004] Fam Law 585. It would appear from the article that the proposal for joint State and ecclesiastical preliminaries was acceptable to the General Synod of the Church of England, but not to the Church in Wales which preferred to retain banns.
} 